\title{
DETERMINANTS OF REAL ESTATE PRICES IN THE STATUTORY CITY OF BRNO
}

\author{
Vlastimil Reichel ${ }^{1}$, Petr Zimčík ${ }^{1}$ \\ ${ }^{1}$ Masaryk University - Department of Economics, Lipová 4la, Brno, Czech Republic
}

\begin{abstract}
REICHEL VLASTIMIL, ZIMČÍK PETR. 2018. Determinants of Real Estate Prices in the Statutory of Brno. Acta Universitatis Agriculturae et Silviculturae Mendelianae Brunensis, 66(4): 991-999.

The real estate market demand for both-houses and flats has been growing recently. This trend is one of the factors, which are able to influence the price of real estate. Our paper introduces determinants of housing price and their influence on actual real estate prices in the statutory city of Brno. The aim of this paper is to present key determinants of house price and find the hedonic price model, which describes, how determinants affect house price best. Realized prices were analyzed for housing units located in different districts of Brno. Key determinants in this research are a year of sale, an area of flat in square meters, number of rooms, location in districts of Brno, type of masonry and reconstruction. The dataset covers the time period between years 2012 and 2015. Hedonic price model is estimated by the method of ordinary least square. Besides main aim, four assumptions were verified, which should determine the influence on the price of individual determinants in the statutory city of Brno.
\end{abstract}

Keywords: hedonic price model, price determinants, real estate market

\section{INTRODUCTION}

Real estates are goods with a different structure. Property distinguishes from each other by their respective space allocation, orientation, building materials, number of rooms and their disposition, and other elements such as inner equipment. The individual character of real estate results from the demand of economic agents. The aim of this research is to identify and analyze main determinants of house price in the statutory city of Brno, and subsequently, find a suitable model specification to correctly predict prices of real estates based on selected determinants.

House price is an outcome of the intersection of a real estate market 's supply and demand. Císař (1996) defines real estate market as a component of the general market system, which is subject to the standard market regularity with possible deviations. It is determined primarily by nature of traded estate (non-transferability, service-life, etc.). In other words, the price of the estate is determined by consumer's decision. They compare gains obtained from house purchase with inevitable costs. According to Sirmans et al. (2003), the theory of hedonic prices is one of the theories, which deal with a problem of supply price-setting on real estate market. The theory of hedonic price model was developed to work with a property, which has distinct characteristics but still are part of the same group of objects (in our case real estate). These products are generally called differentiated goods. The hedonic price model tries to identify price determinants depending on its quantitative and qualitative characteristics (due to the type of analyzed product). It also assumes that finding of key determinants enables us to calculate sign and size of each determinant on final price separately.

Court (1939), Haase (1992) or Wallace (1926) are often considered as founders of the hedonic price model concept. Their work, however, was not primarily focused on real estate price determinants. Authors, who as first used the concept of the hedonic price model to evaluate real estate, were Lancaster (1966) and then later Rosen (1974), Jud, Seaks and Winkler (1996) and also Helbich, Brunauer, Vaz, and Nijkamp (2014). These authors pointed to relevant real estate price 
determinants, such as a size of estate unit and its disposition, attractiveness of locality and others. Models of hedonic price used to evaluate real estate are usually based on inner or outer physical features of the property (size, disposition, type of property), locality variables in neighborhood (school or shop availability, quality of near houses, public services in the area) and other factors linked to the property (age of the property). Sirmans et al. (2006) point out, that most of the inner or outer factors have a positive relation to the price of the property. Nevertheless, there are also some which lower the price (age, energy intensity, etc.). a similar conclusion can be seen in Clark and Herrin (2000), Fletcher et al. (2000), Cebula (2009), Elbru (2011) and Kim et al. (2015). Generally, we can claim, that these studies agree on positive link between the disposition of property or size of living area, and selling price of the estate. The trend between them is not necessarily linear. Value of the property generates also other relevant aspects such as building material of property or technical equipment. The authors usually claim that price of estate grows with a higher quality of building material. Next important factor is the year, in which sale of real estate was realized. The relevance of time factor is strengthen considering a real business cycle effect on the real estate market (see Čadil, 2009; Hlaváček and Komárek, 2010; Zemčík, 2011; Hlaváček et al., 2016, or Brůha et al., 2017). This factor is able to capture macroeconomic influences and their effect on the market development in our observed period (2012-2015). Chosen period is characterized by a decline of mortgage interest rates in the Czech economy. This is one of the main reasons behind increased demand for mortgage loans and, ultimately, increased demand for real estates. The economy also faced to lower supply of real estates in the same period due to losses of some developers in after-crisis era since 2009 (see Hloušek, 2016a or Hejlová et al., 2017). Both of these facts lead to the same conclusion-an increase in real estate price.

Studies of Malpezzi (2002), Sirmans and Macpherson (2003) belong among compilation studies with a summary of knowledge about the hedonic price model. The publications recapitulate development of the hedonic price modelling, divide characteristics of property into subgroups and describe in detail individual variables and their effects with estimates of coefficients sizes.

This study is primarily focused on determinants, which reflect inner, outer, space and time characteristics of real estate. First, we discuss relations of each key variable to a price of the property. Disposition of property is positively correlated with its price. An additional number of rooms increases the price per $\mathrm{m}^{2}$. In other words, property with more rooms is preferable than the one with fewer rooms and we can expect a higher price for it. The second key determinant is the material composition of property, where superior building materials increase the price of a property. The third is the location of the property within the city of Brno. We anticipate the higher price of the property closer to the city center. Last key determinant is the year, in which real estate was sold. We presume the value of a property to grow in time nominally. Taking into account span of our data sample (2012-2015), we primarily expect a linear growth. Relations of each variable to property price will be verified using mathematically-statistic methods applied on carefully collected data sample.

Structure of this article is as follows: First, nature of collected dataset is discussed. Second, formulation of used hedonic price model is described together with all modifications. Third, estimates of model parameters are conducted and their informative value is discussed in accordance with the theoretical prediction. Next, four assumptions from the beginning of the article are verified. The last chapter contains a comparison of prediction ability of each model.

\section{MATERIALS AND METHODS}

In this paper, we use a cascade of hedonic price models. Parameters for these models are estimated using ordinary least squares (OLS) method (see Koop, 2008 or Cipra, 2008). Regression with OLS estimates is commonly used to estimate the relation of specific characteristics of the property and its sale price. Scientific outcomes differ among many studies, not only in size of coefficients or statistical significance but even in a resulted sign of coefficient (see a summary study of Malpezzi, 2002 and Sirmans and Macpherson, 2003).

Said regression estimate is often designated as the model of the hedonic price. Specific model used in our study can be described by the following equation:

$P M=\alpha+\beta_{1} \times T R+\beta_{2} \times L+\beta_{3} \times V+\beta_{4} \times P+\beta_{5} \times$
$\times M+\beta_{6} \times R+\varepsilon$

where $\alpha$ is a constant, $\beta_{i}$ is a vector of estimated coefficients, PM is dependent variable expressing realized the price of real estate per square meter. TR marks time trend, L location, $\mathrm{V}$ acreage, $\mathrm{P}$ number of rooms, $\mathrm{M}$ type of building material and $\mathrm{R}$ information if the property was reconstructed or not. $\varepsilon$ is error term. All named regressors are also used as control variables. In case of adequate estimation, individual variables are going to be replaced with dummy variables to discuss basic assumptions. Dummy variables will replace regressors Trend, Room, Material and Location. We assume resulting estimates to help either confirm or disprove assumptions made in the introduction and commented in chapter 1 . Results of estimated models will be compared and their information value together with prediction ability will be discussed. 
Equations for individual models with substituted dummy variables have the general form of:

$$
P M=\alpha+\sum_{i=1}^{n=-1} \beta_{i} \times W_{i}+\sum_{j=1}^{m} v_{j} \times D_{j}+\varepsilon
$$

where $\alpha$ is a constant, $\beta_{i}$ a $v_{j}$ are regression coefficients, $W_{i}$ is an $(\mathrm{n}-1) \times 1$ vector of control variables with always one omitted variable. This creates dummy variables, which are contained in $\mathrm{m} \times 1$ vector $D_{j}$

The dataset covers the period from 2012 to 2015 and contains exactly 1081 observations of seven characteristics about real estate in the statutory city of Brno ${ }^{1}$. Data were obtained from two largest real estate agencies (by volume of sold real estates in Brno) and four smaller real estate agencies. Due to termination of cooperation with these agencies, the dataset cannot be expanded with additional observations or variables. Our dataset roughly covers one-tenth of all real estate sales realized in an observed period in Brno. We can compare it with information from server realitymorava. cz about 1000 real estates for sale in 2017 to get a better picture of extension of our dataset. Based on the previous, we consider our dataset to be suitable and sufficient for our analysis. Description of all used variables is included in Tab. 1.

Relations between included variables and real estate price (expressed by price per meter squared) are captured in Fig. 1. The Fig. shows rendered factorized box plots. The average price per square meter should be linearly increasing or declining according to our assumptions. This claim is visible practically in all categorized variables.

A gradual increase of average price per square meter in relation to time trend is expected (according to ČNB, 2016). Due to the elastic prices of real estates in the Czech economy, we assume self-clearing real estate market. This does not allow an overhang of demand over supply on the market. An increase in demand (or supply decrease) is directly projected to a price increase. This information is contained within the data, despite statistical non-significance of differences. Development of relation between price and number of rooms is surprising. According to

I: Description of dataset and derived variables

\begin{tabular}{|c|c|c|}
\hline Variable & Shortcut & Description \\
\hline Price & $\mathrm{CN}$ & Realized price of property in CZK (taxes included). \\
\hline Trend & TR & Year of property sale. \\
\hline Location & $L$ & Distance from the city center ${ }^{1}(1=$ center, $4=$ periphery $)$. \\
\hline Acreage & $V$ & Acreage in square meters. \\
\hline Room & $P$ & Number of rooms inside a property. \\
\hline Material & $M$ & Material characteristics of a building. \\
\hline Reconstruction & $R$ & A dummy variable indicating, if the building was reconstructed. \\
\hline \multicolumn{3}{|l|}{ Derived variables } \\
\hline Price per & $P M$ & Proportional variable: Price/Acreage \\
\hline Materiall & M1 & Dummy variable: 1 = new building; 0 = otherwise \\
\hline Material2 & M2 & Dummy variable: $1=$ brick + not reconstructed; $0=$ otherwise \\
\hline Material3 & M3 & Dummy variable: $1=$ brick + reconstructed; $0=$ otherwise \\
\hline Material4 & M4 & Dummy variable: 1 = panel + not reconstructed; $0=$ otherwise \\
\hline Material5 & M5 & Dummy variable: 1 = panel + reconstructed; 0 = otherwise \\
\hline Locationl & L1 & Dummy variable: $1=$ center; 0 = otherwise \\
\hline Location2 & L2 & Dummy variable: 1 = first ring; 0 = otherwise \\
\hline Location3 & L3 & Dummy variable: 1 = second ring; 0 = otherwise \\
\hline Location4 & L4 & Dummy variable: 1 = third ring; 0 = otherwise \\
\hline Room & $P \_i$ & Dummy variable: $1=\mathrm{i}$ rooms; $0=$ otherwise $; \mathrm{i}=1 ; \ldots ; 5$ \\
\hline Trend & $T \_i$ & Dummy variable: $1=$ i year; 0 = otherwise; $\mathrm{i}=2012 ; \ldots ; 2015$ \\
\hline
\end{tabular}

Source: Own processing

1 Preliminary estimates on this dataset were published in conference proceedings Reichel and Schenková (2016).

2 Location is divided according to Schenkova (2011). Center includes Staré Brno, Stránice, Veveř́, Černá pole, Královo pole, Pisárky, Žabovřesky a Ponava; the First ring includes Ivanovice, Jundrov, Kníničky, Komín, Lesná, Medlánky, Řečkovice, Sadová a Soběšice; Second ring includes Černovice, Husovice, Komárov, Maloměřice, Obřany, Židenice, Zábrdovice Štýřice a Trnitá; Third ring includes Bohunice, Bosonohy, Líšeň, Starý Lískovec, Slatinu, Žebětín, Bystrc, Nový Lískovec a Kohoutovice. 
the information included in the dataset is economic subject on demand size of real estate market on average less willing to pay for additional room ${ }^{3}$. Need to say, property disposition does not predict the overall size of a property, just an internal arrangement of room numbers. a relation between quality of building material and property price shows drop in average price less quality material usage. This finding is consistent with the claim in Schenková (2009), stated that differences in real estate caused by using variant material (especially in thermal and sound insulation properties).

The highest average price is observed in new buildings, where bricks or concrete blocks used as a building material. Lower average price indicates buildings with reinforced concrete structure skeleton with brick wall and as expected the lowest price is visible for panel buildings.

Variable location was chosen from an assumption of centric location-price orientation in the statutory city of Brno. Meaning that the most expensive real estates should be located in city center and the cheapest one on the periphery. The gradual drop in price with greater distance, however, is not captured in data. The second ring indicates the higher price per square meter than the price in a city center. This may be explained with the highest concentration of new buildings just in the second ring. We can see a gradual decrease in prices with longer distance in centric layout after omission of the new building from the dataset. Another method to a model influence of location on real estate price is to divide city to individual districts. This alternative division should gain more accurate information about location influence. We were not able to do this alternate specification because of an enormous number of the individual district in the city of Brno. We inclined in our research to simple and more suitable specification due to location characteristics of Brno.

\section{RESULTS}

This part present result of five model estimations on a random sample of 700 observations. Remaining 381 observations (from a total of 1081) are used to additional test prediction capabilities of real estate price per square meter. The first regression model of hedonic price is a control model to provide information if we can use the dataset to model real estate market in the statutory city of Brno. Next four models serve to verify the relation between real estate price and key determinants listed in the introduction. Estimated models are marked in ascending order as M1 to M5 and coefficients of estimation are presented in Tab. II.
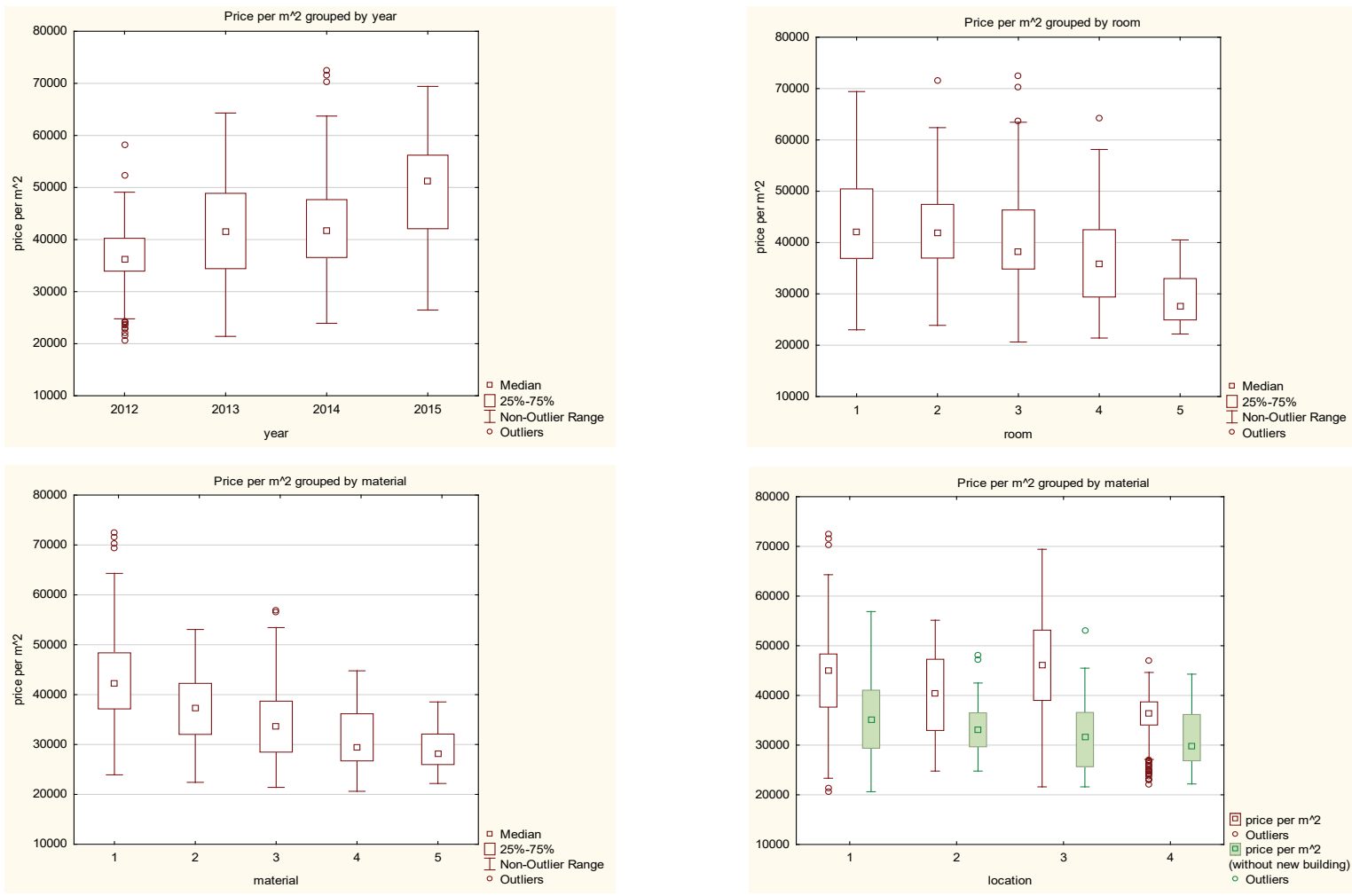

l: Basic numeric characteristic of selected variables Source: Own processing

3 Residential room needs to be at least $8 \mathrm{~m} 2$ large and meets living conditions prescribed by law. 
Model Ml estimates a price of real estate using main control variables selected based on studies of Sirmans and Macpherson (2003), Malpezzi (2002) and Cebula (2009). Our estimates are consistent with outcomes of mentioned authors and can provide information needed to evaluate effects

II: Estimation of individual hedonic price models ${ }^{4}$

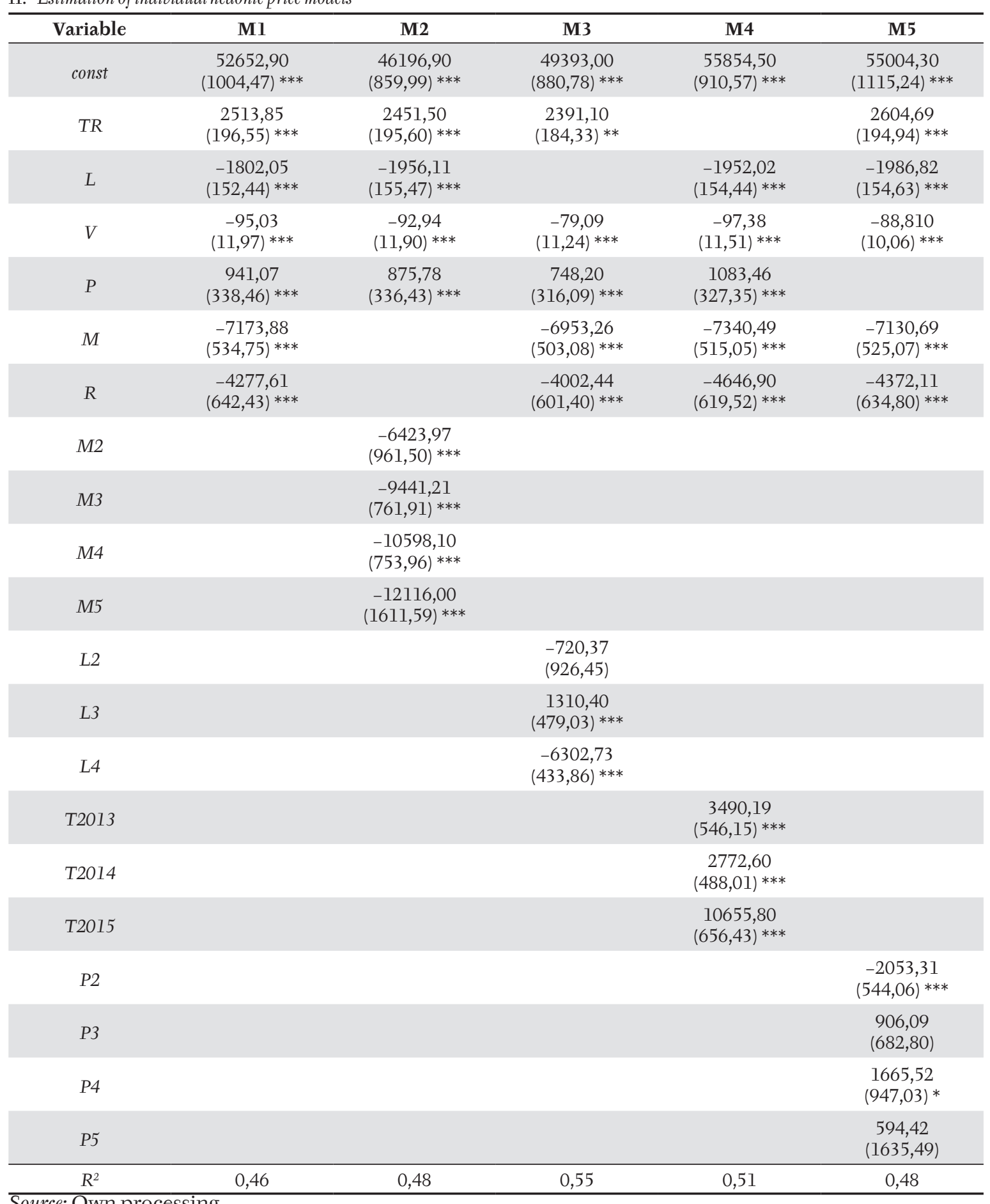

Source: Own processing

4 Appropriate standard deviation for each variable is listed in parentheses. The number of stars next to each deviation represents significance level: $\left({ }^{*}\right) 10 \%,\left({ }^{* *}\right) 5 \%$ and $\left({ }^{* *}\right) 1 \%$. All coefficients and standard deviations are round to two decimal points. The dependent variable is $\mathrm{CN}$-realized real estate price per square meter. 
of each determinant to real estate price. Based on outcome in $\mathrm{Ml}$ is default price of property set to $52,652 \mathrm{CZK}$ per $\mathrm{m}^{2}$. An additional number of rooms projects into price positively. With every other room inside the property, goes the price up about 941 CZK per $\mathrm{m}^{2}$. We can also see consist results with the assumption, that worse quality of building material is negatively projected in the final price of a property. The location also matters, according to our estimates each further ring decreases price linearly by about 1802 CZK per $\mathrm{m}^{2}$. a linear and rising relation can be seen in variable trend. The model then predicts the later period of sale the higher sale price of the same property. Individual control variables are transformed into dummy variables to distinguish additional information inside a selected variable. Dummy variables are chosen in a way, so that model in constant captures reference group matching situation of a variable to have a value equal to zero. For example, in case of variable Location, the constant matches situation, when the property is located in the center of Brno.

Estimates of model M2 provide more detailed outcome about the effect of building material. The model combines information about used material and if the property was reconstructed or not. Reason for this unification was an assumption, that properties from bricks or new blocks (new buildings) are more expensive than buildings with a concrete skeleton and brick walls and also that property from reinforced concrete structure panels are the cheapest. Estimates results in Tab. II confirm this assumption. They also show a lower price for a reconstructed property ${ }^{5}$. This paradox can be explained by age of the property. An older real estate is generally cheaper than newer even after reconstruction, Malpezzí (2002). Unfortunately, our dataset does not contain information about the age of buildings, so we cannot prove this assumption.

Model M3 is focused on identification of location determinants. The difference against model Ml is that we cannot confirm the assumption of a higher price per square meter for property closer to the city center. Estimates clearly indicate the highest price for property not in the center but in the second ring. Also, our assumption of linear price growth is not confirmed by results. The only confirmed premise is a difference between last ring and the reference group, which is city center. As mentioned before, this information can be biased due to a high concentration of new buildings in the second ring.

Model M4 captures successive growth in real estate price, posted by Czech National Bank in its annual reports since the year 2009. High demand caused by still decreasing mortgage interest rates together with an insufficient supply of new buildings affects the persistent pressure of supply and realized the price of resident properties. M4 indicates this persistent trend not to be constant but rather progressive in 2015. One of the explanations is the Zero lower bound (see Hloušek, 2016b). Low mortgage interest rates enabled to obtain cheap mortgage loans, hence an increase in real estate demand. Impact of these cheap loans showed up later (since 2013) because of the caution of economic agents induced by the crisis. Exchange

III: Prediction criteria of used models

\begin{tabular}{lccccc}
\hline \multicolumn{1}{c}{ Criterian } & M1 & M2 & M3 & M4 & M5 \\
\hline MSE & 40723580 & 39884550 & 38997829 & 41004169 & 42110557 \\
RMSE & 6382 & 6315 & 6245 & 6403 & 6489 \\
MAE & 4956 & 4749 & 4695 & 4884 & 4992 \\
\hline
\end{tabular}

Source: Own processing

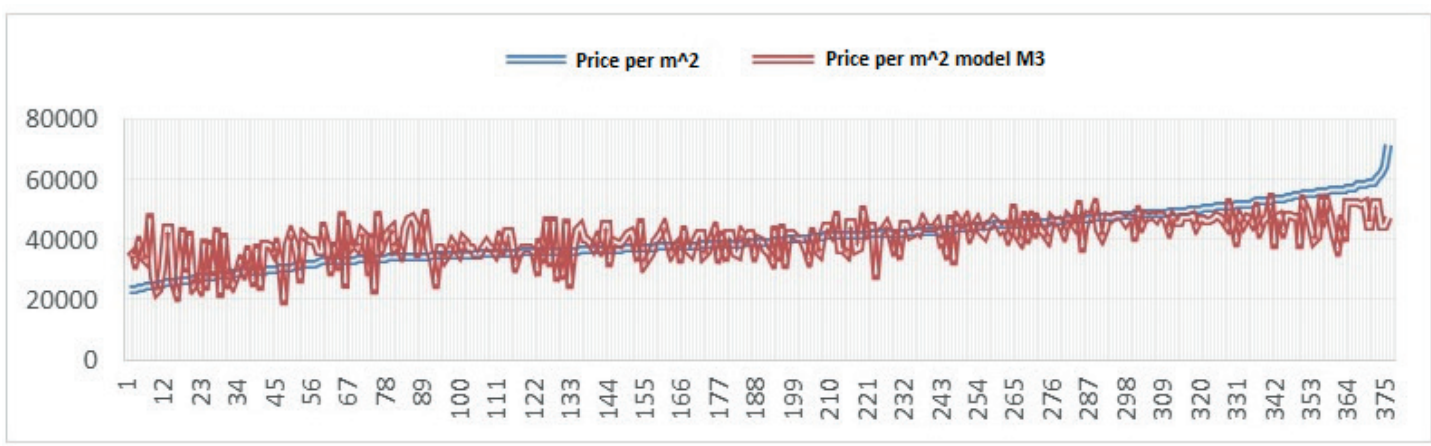

2: Comparison of realized and predicted values in model M3

Source: Own processing

5 This outcome is in contradiction to the one in conference proceedings of Reichel and Schenková (2016). An outcome in mentioned proceedings was due to bias caused by redundant variable, which was omitted in our study 
rate interventions of the Czech National Bank, which started in fall 2013, could also contribute to this phenomena. Foreigners, who cheaply bought Czech currency in pursuit of profit, could see investment in properties as one of their option. Investment decision to purchase property pushes demand on real estate market upwards and the price to be elevated. There has also been a drop in construction of new real estates in the post-crisis period after 2009, which cause a decrease in real estate market supply (see Reichel and Gajdošová, 2017). The combined effect of demand increase and supply drop strengthen rise in real estate prices. Continuation of this accelerated boost could possibly lead to another bubble in this market. CNB reacted to the situation by a recommendation to lower maximal LTV of individual commerce banks in 2016. This limitation should demonstrate itself in the way several economic agents, who demand mortgage loan, not to meet a requirement and ultimately fail to obtain the loan. This should lower excessive demand on the real estate market and thus lower the price of real estates.

Model M5 is targeted on possible price influence of additional room inside property. We expected property with a higher number of rooms to have a higher price per square meter than property with same acreage but fewer rooms. We cannot conclusively validate this assumption of linear relation with our estimates. Coefficients P2 up to P5 do not have an increasing trend $(\mathrm{P} 5>\mathrm{P} 4>\mathrm{P} 3>\mathrm{P} 2$ does not apply), moreover they are not statistically significant. Therefore, we cannot confirm the hypothesis about increasing price per square meter with a higher number of rooms.

Predictions of individual models were performed based on parameter 's estimates and remaining observations. Three types of criteria were used in our study: mean square error (MSE), root mean square error (RMSE) a mean absolute error (MAE). Values of each criterion are captured in Tab. III. In general, lower value of criteria means better prediction capabilities of the model. Comparison of prediction capabilities look as follows $\mathrm{M} 3>\mathrm{M} 2>\mathrm{M} 1>\mathrm{M} 4>\mathrm{M} 5$, with M3 to have highest prediction capability.

We also graphically visualized prediction capabilities using realized prices of real estates in the ascending order together with our prediction prices. Graphic outputs of individual models are very similar to each other. Because of that, Fig. 2 contains output only for our best prediction model, according to Tab. III-M3. Practically all models were unable to sufficiently predict price for the most and least expensive real estates, which can indicate the absence of additional information or characteristics making model more accurate.

\section{DISCUSSION}

The aim of this article was to identify and analyze the main determinants of real estate price in the statutory city of Brno and find the most suitable model specification, which use these determinants to accurately predict real estate price. Our analysis contained of cross-sectional data with over thousand realized sales of real estates (not only offers from real estate agencies) and information about each property. Cascade of hedonic price model was used to identify size and sign of each determinant 's effect. Least ordinary squares were used as a method of estimation. The results partially support our assumptions about effects of determinants on property price stated in the introduction and also largely coincided with findings of authors focusing on a similar issue, such as Sirmans and Macpherson (2003) and Malpezzí (2002).

All expected relations between price determinants and actual prices of real estates in model Ml were verified in our study. More detailed results, however, revealed some of the expected relations to be statistically non-significant. The assumption about the positive effect of additional rooms inside the property on its price per square meter was not rejected in models M1 to M4. Model M5 pointed out that property with two residential rooms is surprisingly cheaper on average than property with one residential room. Properties with three to five rooms are the most expensive. The assumption about a positive relationship between quality of building material and price per square meter was verified in all models. All models except for M3 support claim about a distance of the property from the city center. Model M3 indicated that real estate prices are highest in the second ring and not in the actual center of the city. However, this result might be biased by a large concentration of new buildings in the second ring. If we omit new buildings from an analysis, the results would be consistent with our centroid assumption. All our models also affirm positive influence of time trend on real estate price. M4 did not capture price increase between years 2013 and 2014, but this can be explained by zero inflation measured by Czech National Bank. Nevertheless, more complex view shows the increasing trend.

Assessment of prediction capabilities was made from estimate results using three prediction criteria. They evaluated prediction capabilities of models in this order: $\mathrm{M} 3>\mathrm{M} 2>\mathrm{M} 1>\mathrm{M} 4>\mathrm{M} 5$. a weakness of all five models is an implausible prediction for the most and least expensive real estates. Filtration of these extreme values significantly improves prediction capabilities of all models. Therefore, we can anticipate hidden factors behind price setting of these extreme cases. It is essential to closely observe the most extreme observations in future research so there would be a minimal bias caused by this disproportion.

Future research can be enriched with the creation of a new dataset with additional variables, such as the architectural design of the property or outer economic environment. These new characteristics can even further influence the price of real estates and improve prediction of our estimation. 


\section{CONCLUSION}

The real estate market is a popular topic in recent decades in the Czech Republic. Over the past twenty years, this market has moved from a non-market structure to a fully market-based structure. Thanks to these developments, we are now able to identify significant determinants that affect the magnitudes in this market both from a microeconomic and macroeconomic point of view. Our paper introduces determinants of housing price and their influence on actual real estate prices in the statutory city of Brno. The aims of this paper was to present key determinants of house price and find the hedonic price model, which describes, how determinants affect house price best. Using OLS estimates of the regression model, we have identified these determinants. The result of the paper is an original survey of the given territory for a given period. In the future, it can provide a basic idea of determining the prices of real estate in the City of Brno, and may also be inspiring for further research on this territory. In summary of our article, we can state, that price of real estates in the statutory city of Brno is driven by the market mechanism, which can be seen in other large cities of Europe.

Acknowledgemen

This paper was supported by the specific research project MUNI/A/0966/2017.

\section{REFERENCES}

BRŮHA, J., HLAVÁČEK, M. and KOMÁREK, L. 2017. House Prices and Household Consumption: The Case of the Czech Republic. Working Papers 2017/11. Czech National Bank, Research Department.

CEBULA, R. J. 2009. The Hedonic Pricing Model Applied to the Housing Market in the City of Savannah and the Savannah Historic Landmark District. Review of Regional Studies, 39(1):9-22.

CIPRA, T. 2008. Finanční ekonometrie. $1^{\text {st }}$ Edition. Praha: Ekopress.

CLARK, D. E. and HERRIN, W. E. 2000. The Impact of Public School Attributes on Home Sale Prices in California. Growth and Change, 31(3): 385-407.

COURT, A. T. 1939. Hedonic Price Indexes with Automotive Examples. The Dynamics of Automobile Demand. New York: General Motors.

ČADIL, J. 2009. Housing Price Bubble Analysis - Case of the Czech Republic. Prague Economic Papers, 18(1):38-47.

ČESKÁ NÁRODNÍ BANKA. 2016. Zpráva o finanční stabilitě. Praha: Česká národní banka.

EBRU, C. and EBAN, A. 2011. Determinants of house prices in Istanbul: a quantile regression approach, Qual Quant, 45(2): 305-317.

FLETCHER, M., GALLIMORE, P. and MANGAN, J. 2000. Heteroskedasticity in hedonic house price models. J.Prop., 17(2): 93-108.

HAAS, G. C. 1992. A Statistical Analysis of Farm Sales in Blue Earth County, Minnesota, as a Basis for Farm Land Appraisal. Masters Thesis. The University of Minnesota.

HAAS, G. C. 1992. Sale Prices as a Basis for Farm Land Appraisal. Technical Bulletin 9. St. Paul: The University of Minnesota Agricultural Experiment Station.

HEJLOVÁ, H., HLAVÁČEK, M. and KOMÁREK, L. 2017. A Comprehensive Method for House Price Sustainability Assessment in the Czech Republic. Prague Economic Papers, 26(3): 269-285.

HELBICH, M., BRUNAUER, W., VAZ, E. and NIJKAMP, P. 2014. Spatial heterogeneity in hedonic house price models: The case of Austria. Urban Studies, 51(2):390-411.

HLAVÁČEK, M. and KOMÁREK, L. 2010. Rovnovážnost cen nemovitostí v České republice. Politická ekonomie, 58(3): 326-342.

HLOUŠEK, M. 2016a. An Estimated DSGE Model with a Housing Sector for the Czech Economy. Statistics and Economy Journal, 96(4): 37-55.

HLOUŠEK, M. 2016b. The Empirical Implications of the Zero Lower Bound on the Interest Rate: The Case of the Czech Economy. Acta universitatis agriculturae et silviculturae Mendelianae Brunensis, 64(2): 603-616.

JUD, G. D., SEAKS T. G. and WINKLER. D. T. 1996. Time on the Market: The Impact of Residential Brokerage. Journal of Real Estate Research, 12(3): 447-458.

KIM, H., PARK, S. and LEE, S. 2015. Determinants of House Prices in Seoul: The Quantile Regression Approach. Pacific Rim Property Research Journal, 21: 91-113.

KOOP, G. 2008. Introduction to econometrics. Chichester: John Wiley \& Sons.s.

LANCASTER, K. J. 1966. A New Approach to Consumer Theory. Journal of Political Economy, 74(2): 132-157.

MALPEZZI, S. 2003. Hedonic Pricing Models: A Selective and Applied Review. In: SULLIVAN, T. O. and GIBBS, K.(Eds.). Housing Economicsand Public Policy: Essaysin Honorof Duncan Maclennan. Blackwell Publishing.

REICHEL, V. and GAJDOŠOVÁ, J. 2017. Historical development and current problems of Czech housing sector. In: Hradecké ekonomické dny 2017. Hradec Králové: Univerzita Hradec Králové, 2017. pp. 730-736.

REICHEL, V. and SCHENKOVÁ, K. 2016. Determinants of housing price: data analysis of city Brno. In: Hradecké ekonomické dny 2016. Hradec Králové: Univerzita Hradec Králové, 2017. pp. 882-888. 
ROSEN, S. 1974. Hedonic Prices and Implicit Markets: Product Differentiation in Pure Competition, Journal of Political Economy, 82(1): 34-55.

SCHENKOVÁ, K. 2009. Materiálová charakteristika realizované i plánované bytové výstavby ve Statutárním městě Brně a její vliv na tržní cenu bytové jednotky. In: Sborník anotací I. Forenznè védecké konference Ústavu soudního inženýrstvíVUT v Brně. Brno: ÚSI VUT.

SCHENKOVÁ, K. 201l. Vliv situování nemovitosti k bydlení jako primární aspekt ovlivňující její obvyklou cenu a postavení na trhu. In: Sborník anotací konference Junior Forensic Science Brno 2011. Brno : Vysoké učeni technické v Brně, Ustav soudniho inženýrství, pp. 24-24

SIRMANS, G. S. and MACPHERSON D. A. 2003. The Valuation of Housing Characteristics. Research Paper Completed for the National Association of Realtors.

SIRMANS, S., MACDONALD, L., MACPHERSON, D. and ZIETZ, E. 2006. The value of housing characteristics: a meta analysis. The Journal of Real Estate Finance and Economics, 33(3): 215-240.

WALLACE, H. A. 1926. Comparative Farmland Values in Iowa. Journal of Land and Public Utility Economics, 2: 385-392.

ZEMČÍK, P. 2011. Is There a Real Estate Bubble in the Czech Republic? Finance a úvèr, 61(1): 49-66.

Vlastimil Recichel: reichel.v@mail.muni.cz

Petr Zimčík: petr.zimcik@mail.muni.cz 